\title{
A Narratological Study and Analysis of: The Concept of Time in William Faulkner's "A Rose for Emily"
}

\author{
Moussa Ahmadian \\ Dept. of English Language and Literature, Faculty of Humanities, Arak University \\ Arak 38156-8-8349, PO. Box: 879, Iran \\ E-mail: M.Ahmadian@araku.ac.ir \\ Leyli Jorfi (Corresponding Author) \\ Dept. of English Language and Literature, Faculty of Humanities, Arak University \\ Arak 38156-8-8349, Iran \\ E-mail: j_le1990@yahoo.com
}

Doi:10.7575/aiac.alls.v.6n.3p.215

Received: 18/02/2014

URL: http://dx.doi.org/10.7575/aiac.alls.v.6n.3p.215

Accepted: 29/04/2015

\begin{abstract}
This study is primarily concenrned with applying Genette's narratological framework of time to the study of William Faulkner's A Rose for Emily. This study aims to provide insights about the time shift processes in this short story. Moreover, since time is a component of narratology, this study will be concerned with discussions about 'narratology' and 'narrative', too. The study falls into two parts. The first section is allocated to the theoretical concepts of 'narratology', 'narrative', and 'time': 'Narratology' which is the study of narrative structures, includes many elements such as mood, voice, narration, as well as time (which is the focus of this study). 'Narrative' is the product of narration and it is what narratologists study and analyze. Furthermore, 'time'-the main focus of this paper-will be elaborated on and then identified in A Rose for Emily based on Genette's two fundamental dichotomies of 'story time' and 'discourse time'. These theoretical discussions are taken into consideration while analysis of $A$ Rose for Emily. The second section, will be devoted to the analysis of time using Genette's model on Faulkner's A Rose for Emily. For this aim, Genette's concept of time which is classified into categories of order, duration, and frequency as well as their subcategories (which are already explained in the first section), will be identified and the shifts that have occurred will be determined.
\end{abstract}

Keywords: narratology, narrative, time shift, Genette's model, A Rose for Emily

\section{Introduction}

Narratives, technically, refer to works of literature like novels or short stories. Narativity is a feature that deals with speech and not visual arts (Lessing, 1962). Narratives, especially short stories, are made up of some components of narratology, one of which is 'time'. Scheffel, Weixler, and Werner (2013) define time in a broad sense as 'time is a constitutive element of worlds and a fundamental category of human experience' (p. 1). They then define time in a narrower sense. They define it from the perspective of narrative theory, as "time is both a dimension of the narrated world (as conceived in the broader sense) and an analytical category ('tense') which describes the relation between different narrative tiers" (ibid.). Furthermore, the relations between time and narrative is not deniable, as Bruner (1991) put it, 'a narrative is an account of events taking place over time. It is irreducibly durative' (p. 6). The notion of time in Faulkner's short story: "A Rose for Emily", is challenging in that Faulkner has manipulated "time" in his distinctive and unique way. He does not rely on a conventional linear approach in this short story, but what we, as readers, perceive is the continuous shifting, stretching, and breaking the linear order of time. The present study is based on Gennette's model of time which relies on the two concepts of 'discourse time' and 'story time'. 'Discourse time' is the time 'it takes to persue the discourse' (Chatman, 1978, p. 62); 'story time' emerges from 'the interplay of space, events, characters, and plot structure (Scheffel et al., 2013). To borrow Genette's term, story time and discourse time are deformed in their duration i.e. they are not the same, but deviate from each other. Genette calls this sort of plays with time 'anisochrony' $(\underline{1980}$, p. 86). What follows, is a review of the main concepts and theories concerning the issues of narratology, narrative, and their inseparable component: 'time'.

\section{Narratology}

Narratology is the study and the analysis of narrative originally established by Tzevan Todorov. The study of narrative, as put forward by Fludernik (2006), is narrative theory. Narrative theory, or to use the internationally accepted term narratology, is the study of narrative as a genre. Its objective is to describe the constants, variables and combinations typical of narrative and to clarify how these characteristics of narrative texts connect within the framework of 
theoretical models (typologies) (ibid, p. 8). To further define narratology, we may refer to Phelan (2006) who reports that Todorov defines narratology as the theory of the structures of narrative. Moreover, Prince (1990) believes narratology helps to show the structure of narrative, and practices something that illuminates temporality and human beings as temporal beings. To Prince narratology has crucial implications for our self-understanding. In a similar vein, Bal (1991) states "narratology is the theory of narrative text. A theory is a systematic set of generalized statements about a particular segment of reality. The segment of reality, the corpus, about which narratology attempts to make its pronouncement consists of narrative text" (p. 264).

Narratological studies embrace two phases: 1) the classical phase, and 2) the post classical phase. "During its initial or classical phase, from the mid-1960s to the early 1980s, narratologists were particularly interested in identifying and defining narrative universals" (Meister, cited in Hune et al, 2009, p. 329). This tendency was in air even a decade later in 1993 which is evident in a definition of narratology from those years: "the set of general statements on narrative genres, on the systematics of narrating (telling a story) and on the structure of plot" (Ryan \& von Alphen, 1993, p. 110). However, a decade later, narratology was alternatively described as (a) a theory (Prince, 2003, p. 1), (b) a method (Kindt \& Müller, 2003, p. 211), or (c) a discipline (Fludernik \& Margolin, 2004, p. 149). The third option seems more suitable since it subsumes the two previous temrs, i.e., theory and method. Discipline is a term that covers both theoretical and application-oriented approaches to narrative and in the realm of narratology.

The second phase in narratological studies is the post-classical phase. Over the past twenty years, narratologists have paid increasing attention to the historicity and contextuality of modes of narrative representation as well as to its pragmatic function across various media. So narratology is not limited to one theory and one discipline, but it can be said that narratology, in post-classical view, is a discipline which is wide enough in scope to be applied to other disciplines. Accordingly, Todorov (1969) states that "narratology is more than a theory. While it may not have lived up to the scientistic pretension expressed in its invocation as a new science of narrative it does qualify as a discipline" ( $p$. 10). As quoted from Rimmon-Kenan (2004), the transition to post-classical narratology is a 'shift from a fairly unified discipline to one characterized by a diversity of approaches' (p. 47). This phase is the time for emergence of interdisciplinary approaches like 'feminist narratology', 'cognitive narratology', 'post-modern narratology', and many other sub-disciplines (ibid., p. 49). Thus, there appears to be two viewpoints toward the concept of narratology. In one, we are faced with the "formalist-structuralist discipline" as called by Rimmon-Kenan (2004, p. 44), and in the second, some inter-disciplinary narratology emerges which opens the ground for more practical and in-depth studies.

\section{Narrative}

Another consideration important to narratological studies is the term 'narrative'. We need to know what a narrative is, what its definition(s) is/are, and what components it has. 'Narrative' in its broad sense may refer to a variety of genres. According to Barthes (1977), "the narratives of the world are numberless" (p.20). The essence of this sentence is reflected in the writings of other figures, as well. Fludernik (2006), for instance, believes that "narrative is all around us" (p. 1). But when we speak about narrative, we inevitably think of a 'literary' form, short story or novel. Fludernik writes, narrative is related to the verb 'narrate' and that narrative is all around us, not just confined to novels or historical writings (ibid., p. 1). She further broadens the scope of narrative to 'narration' and declares whatever is narrated is a narrative:

Narrative is associated above all with the act of narration and is to be found wherever someone tells us about something: a newsreader on the radio, a teacher at school, a school friend in the playground, a fellow passenger on a train, a newsagent, one's partner over the evening meal, a television reporter, a newspaper columnist or the narrator in the novel that we enjoy reading before going to bed. We are all narrators in our daily lives, in our conversations with others, and sometimes we are even professional narrators (should we happen to be, say, teachers, press officers or comedians). (ibid., p. 1)

Nash (1994) holds a similar perspective toward narratives and says that narratives in one form or another permeate virtually all aspects of our society and social experience. Narrative forms are found not only in the context of literature but also in the recollection of life events, in historical documents and textbooks, in scientific explanations of data, in political speeches, and in day-to-day conversation (p. xi).

In the above definitions, a sort of ubiquitous nature is devoted to narratives, i.e. they are considered to cover a broad range of modes of expressions. Against these definitions which allocate a wide scope to narratives, Abbot explains that other narratologists (Genette, 1980; Prince, 1987; Chatman, 1978) define narrative in a limited sense as an act of storytelling addressed by a narrator to a narratee, or as the recounting of a sequence of past events (Abbott, 2002). As it is evident in this definition, a condition is assumed for a work to be considered narrative, and that is the occurrence of the speech act of telling a story by an agent called a narrator. Furthermore, this definition stresses the telling of a story by a narrator which emphasizes a language-based phenomenon, excluding visual or musical narrative forms.

Narrative has been also defined by Toolan (2001) in this way: "narrative is a perceived sequence of non-randomly connected events, typically involving, as the experiencing agonist, humans or quasi-humans, or other sentient beings, from whose experience we human can learn (p. 2). It seems that for Toolan the feature of "event sequence" is a necessary feature of a narrative. 
There are some major characteristics for a narrative discussed by Toolan (2001). They are as follows: a) a degree of artificial fabrication or constructedness, b) a degree of prefabrication, c) having "trajectory" meaning that they have a beginning, middle, and an end (as Aristotle's discussion in his Poetics), d) having a "teller" (even if he is invisible), e) having the feature of "displacement" (the ability of human languages to be able to refer to things or events that are removed, in space or time, either from the speaker or the addressee) f) narratives involve the "recall" of happenings (pp. 4-5).

\section{The Concept of "Time"}

Narratology is made up of many elements and facets. As a framework, narratology includes different genres and levels, which analyses different characteristics of a narrative such as story, action, tellability, focolization (mood), narration (voice), time, tense, narrative modes, narrative situation, discourse, and characters. Among these elements, 'time' is considered in this study.

The concept of time is one of the components of narratology. Scheffel et al. (2013) states that time is not observable but it becomes manifest and thus perceivable in various changes (e.g. event) (p. 1). One of such manipulations is the use of time in narratives. Ricoeur (1984-1987) devoted a three-volume monograph to this issue, stating that present, past and future, that is, the human experience of time is closely related to the narrative ability. Ricoeur, the preeminent theorist of narrative temporality, writes, for example: "my first working hypothesis is that narrativity and temporality are closely related. . . . [I]ndeed, I take temporality to be that structure of existence that reaches language in narrativity and narrativity to be the language structure that has temporality as its ultimate reference" (Ricoeur, 1981, p. 165). Heidegger's (1971) hermeneutic philosophy also stresses that it is through narrative that we are able to bring past experiences or future events into the present and make them part of present existence. Heidegger moreover believes that the ordinary representation of time as a linear series of 'nows' hides the true constitution of time.

Together with spatial parameters of height, width, and depth, time is the fourth dimension which makes it possible to locate and measure occurrences (Scheffel et al., 2013). Besides, time is seen and interpreted differently by different people and cultures. Thus, time is a culturally constructed concept, and it varies as a result of historical evolutions (Scheffel et al., 2013) or maybe cultural changes.

Time is a complex phenomenon and is not understood unless in a coherent and tangible framework. Due to its elementary quality, time is widely discussed in philosophy, physics, and aesthetics. St Augustine claims that "time is hard to grasp even though one has an intuitional notion of it" (Augustine, 1992, p. 154). Lessing (1962) believes the art of speech (poem and fiction), as opposed to visual art, takes place within time. In particular, narratives, understood as representations of event-sequences, are defined and differentiated by their temporality.

In discussions about sequentiality and eventfulness, time, along with causality, is considered by some theoreticians to be a necessary condition for narrativity (e.g. Tomaševskij, 1965. p. 66; Todorov, 1971. p. 38). The temporal dimension is thus used to differentiate between narrative and non-narrative types of text (Herman, 2009, pp. 75-104). From what scholars say, it seems that 'time' plays a crucial role in determining the narativity of a work and thus is a unified concept which should be carefully studied and examined. The study of time, thus, needs some frameworks.

In the discussion of time, the sequence and order of events are important features of stories. There exist some discrepancies between story time and discourse time. This feature should be taken into careful consideration when analyzing a story. Roughly speaking, the distinction between 'story' and 'discourse' corresponds to the fundamental distinction between 'fabula' (story) and 'sjuzet' (narrative discourse), as introduced by Shklovsky and the Russian Formalists in the early 20th century - the story or fabula is the 'natural' (i.e. linear, chronological) state but discourse or sjuzet is the temporal and spatial reconstruction of that story by the writer (or narrator). In other words, fabula/ story refers to "what" is being told whereas sjuzet/ discourse refers to "how" a story is being told and "how" a story writer/teller manipulates a story. Thus the same fabula can be reconstructed is different ways by different writers.

The two concepts of story/ narrated time and text/ discourse/ narrating time are distinguished. Story time refers to the actual duration of events in the story. It is the sequence of events and the length of time that passes in the story. Discourse-time, on the other hand, covers the length of time that is taken up by the telling (or reading) of the story and the sequence of events as they are presented in discourse. In narrative analyses of time, the relationship between these two concepts are examined. Muller (1948), cited in Fludernik (2006), notes that "the pace of narrative derives from the relation between discourse time and story time" (p. 32). This relation is rarely 'isochronic'. To borrow Genette's term, story and discourse time are "anisochronic" in most cases (Genette calls the deformation of 'duration' 'anisochrony' (Genette, 1980, p. 86). In analyze story time and discourse time, Genette utilizes three concepts of order, duration (speed of events), and frequency of events (ibid., pp. 33-113). Structuralism analyzes time by studying the relation between the time of the story and the time of narrative (Herman \& Vervaek, 2005). Figure 1, aims to show the structuralists' classification of time: 


$$
\text { - Duration }
$$

- Order

$\begin{array}{ll} & \square \text { distance } \\ & \square \text { reach } \\ \text { - Frequency } \quad \square \text { singulative }\end{array}$

$\square$ iterative

\section{$\square$ repetitive}

Figure 1. The classification of 'time' based on structuralism Cited from Herman \& Vervaek, 2005, p. 60.

The first factor in the analysis of time, according to the framewok proposed by Genette, is the duration/ speed of events. Genette uses theatrical performances as his basis. In theater, story time and discourse time are mostly the same, i.e., they are isochronic according to Genette (it means what actually happens, takes the same time/ duration as what the audience see). Anisochronic time occurs on the level of text where the narrator can speed up or slow down the narration with respect to the events being told. For example, we can summarize someone's entire life in a single sentence, or we can take a thousand pages to recount events occurring over a 24-hour period (Fludernik, 2006).

\subsection{Duration}

Duration is the relation between story time and discourse time. Genette describes four distinct modes for the mapping of story-time to discourse-time (1980, p. 94), to which Prince (1982) added a fifth "stretch" (p. 56). The following table is a summary and a classification of the category "duration". After that, it is attempted to define and elaborate each term in more details.

Table 1. The five types of anisochrony

\begin{tabular}{|c|c|}
\hline Mode & The relation between story time (ST) and discourse time (DT) \\
\hline a. Ellipses & Periods of ST are completely omitted from discourse \\
\hline b. Summary & Periods of ST described in less DT than usual \\
\hline c. Scene & $\begin{array}{l}\text { Consistent match between ST and DT. Generally, actions take the } \\
\text { same relativeamount of time to describe as they took in the 'reality' of } \\
\text { the fabula. }\end{array}$ \\
\hline d. Pause & $\begin{array}{l}\text { Passing of ST temporarily suspended to allow for description of a static } \\
\text { setting or for a digression }\end{array}$ \\
\hline e. Stretch & $\begin{array}{l}\text { More DT than ST (i.e. it takes longer to describe an action than actually } \\
\text { elapsed while it was happening). Like filmic slow-motion. }\end{array}$ \\
\hline
\end{tabular}

Cited from Whatling, 2010, 2.2.b. "Temporal Ordering and Pacing"

In the following, these five modes, which are the components of duration, will be explained in more details:

a. Ellipsis: DT $=0 ; \mathrm{ST}=n$. The discourse says absolutely nothing about some part of the event-story, i.e. periods of ST are completely omitted from discourse. Fludernik (2006) notes that "This is to create suspense within the story" (p. 33).

b. Summary: DT < ST. Some part of the event-story is summarized in the discourse, creating acceleration. Summaries can be of variable length.

c. Scene: DT = ST. Narrative (discourse) time corresponds to the story's time. There is a consistent match between ST and NT. Generally, actions take the same relative amount of time to describe as they took in the 'reality' of the story. Dialogue is a good example of this. 
d. Pause: $\mathrm{DT}=n ; \mathrm{ST}=0$. The event-story is interrupted to make room for narratorial discourse. Passing of ST temporarily suspended to allow for description of a static setting or for a digression. Static descriptions fall into this category. The descriptions of landscapes, state of mind, or sociocultural backgrounds are instances of this category.

e. Stretch: DT > ST. It takes longer to describe an action than actually elapsed while it was happening. "Like the cinematic slow-motion.

(Fludernik, 2006)

Needless to say, these five components of duration can be used to varying degrees. They can also be combined: A dialogue scene can contain a summary within it, for example. Variations in speed within a narrative may show the relative importance of an event within a story. Therefore, the author's intention in this respect is important. If the author omits a part and focuses one more, there may be a reason.

\subsection{Order}

The second aspect that Genette introduces, is order. Order is the relation between the sequencing of events in the story and their arrangement in the narrative. A narrator may choose to present the events in the order they occurred, that is, chronologically, or he can recount them out of order. In most cases, the innocent "temporal order" is rarely adhered to. Most discourses flit back and forth along a hypothetical time-line representing the underlying chronology of the story, according to the needs of the story-teller. Deviations from strict chronological order within the discourse is called 'anachronies' by Genette (1980) - and these he divided into two types, depending on whether the discourse was jumping forward or backwards in relation to the story's time. There are two types of anachrony based on Genette (1980):

a. Analepsis (flashback): The narrator recounts after the fact an event that took place earlier than the present point in the main story.

b. Prolepsis (flashforward/foreshadowing): The narrator anticipates events that will occur after the main story ends.

\subsection{Frequency}

Frequency is the relation between the number of times an event occurs in the story and the number of times it is mentioned in the narrative. "A system of relationships is established between these capacities for 'repetition' on the part of both the narrated events (of the story) and the narrative statements (of the text) - a system of relationships that we can a priori reduce to four virtual types, simply from the multiplication of the two possibilities given on both sides: the event repeated or not, the statement repeated or not" (Genette, 1980, p. 114).

Frequency analysis, investigates a narrator's strategies of summative or repetitive telling. There are three main frequential modes (Genette, 1980, pp. 113-160; Rimmon-Kenan, 1983, pp. 46, 56-58; Toolan, 1988, pp. 61-62, cited in Jahn, 2005) as follows:

a. Singulative telling: Recounting once what happened once.

b. Repetitive telling: Recounting several times what happened once.

c. Iterative telling: Recounting once what happened $\mathrm{n}$ times.

Table 2 'Frequency' (repetition in story and in discourse)

\begin{tabular}{ccc}
\hline $\begin{array}{c}\text { Number of times event occurs in } \\
\text { the fabula }\end{array}$ & $\begin{array}{c}\text { Number of times event is } \\
\text { described in the discourse }\end{array}$ & $\begin{array}{c}\text { Form of relationship } \\
\text { (Genette's terms in parenthesis) }\end{array}$ \\
\hline One & Once & 1S: 1D (singulative) \\
Several & Several & nS: nD (singulative) \\
Once & Several & 1S: nD (repetitive) \\
Several & Once & nS: 1D (iterative) \\
\hline
\end{tabular}

Cited from Whatling, 2010, 2.2.b. "Temporal Ordering and Pacing"

Table 2, is a summary of Genette's third category for analyzing time, that is frequency. Singulative frequency, according to Whalting has two forms; when an event happens just one time in the story and is described once in discourse, it is a case of singulative frequency. The other form is whatever number of times an events occurred in the story, it should equally be mentioned in discourse (nS: $\mathrm{nD}$ ). The second type of frequency, repetitive, (as the table shows) is recounting several times what happened only once in the story. The third type is iterative frequency, is when an event that occurred several times in the story, is mentioned only once in the discourse.

\section{The Analysis of time in "A Rose for Emily"}

In the following, the short story "A Rose for Emily" by William Faulkner is to be analyzed from the perspective of narratological time. This study considers $A$ Rose for Emily as a piece of narrative which can be put under study and analysis from narratological perspective. Although narratology encompasses many tools (components) by which a narrative can be analyzed, this study is to treat the narratological time in this short story. Admitting time as a broad concept, Genette's model of time is adopted to put time into a limited manageable framework. 
In "A Rose for Emily”, Faulkner does not rely on a conventional linear approach to present his characters' inner lives and motivations. Instead, he fractures, shifts, and manipulates time, stretching the story out over several decades. We learn about Emily's life through a series of analepsis (flashbacks). The story begins with a description of Emily's funeral and then moves into the near-distant past. At the end of the story, we see that the funeral is an analepsis, as well. This short story is a beautiful mixture of analepsis, i.e. within one broad analepsis there is another analepsis and within the second, a third instance can be found; therefore, it can be said that a sort of layers of analepsis is created. Yet, some prolepsis (flashforward) occurs within those analepsises.

In the analysis section, those parts of the story which deviate from the chronological order or generally speaking, have instances of 'time manipulation', are brought in this paper and then analyzed. It should be mentioned that the italicized words, phrases, and sentences are all mine. This is done to show where exactly time has been manipulated.

The story opens with what I call a "major" analepsis, because it encompasses other (minor) analepsises:

When Miss Emily Grierson died, our whole town went to her funeral: the men through a sort of respectful affection for a fallen monument, the women mostly out of curiosity to see the inside of her house, which no one save an old man-servant - a combined gardener and cook- had seen in at least ten years (para. 1, p. 1).

This is the very opening of the story. It talks about Emily's death which has not happened at the present state of the story, but it is recounting the death of Emily which had happened some years ago. This is a shift in the order of the story, i.e. the normal sequence of event is scrambled by the very opening and readers are taken to some past years, to Emily's death. In this analepsis, an instance of pause is evident in the second paragraph:

It was a big, squarish frame house that had once been white, decorated with cupolas and spires and scrolled balconies in the heavily lightsome style of the seventies, set on what had once been our most select street. But garages and cotton gins had encroached and obliterated even the august names of that neighborhood; only Miss Emily's house was left, lifting its stubborn and coquettish decay above the cotton wagons and the gasoline pumps - an eyesore among eyesores. And now Miss Emily had gone to join the representatives of those august names where they lay in the cedar-bemused cemetery among the ranked and anonymous graves of Union and Confederate soldiers who fell at the battle of Jefferson (para. 2, p. 2).

In the above passage, six lines are allocated to the description of Miss Emily's house. This in-detail description is an instance of "pause". Here, the events in the story are interrupted and the static setting, Miss Emily's house in this case, is being described. Many such other instances of pause occur throughout the story which will be identified in the coming analysis.

In paragraph 4, there are two phrases that guide us to a better analysis and to indicate the type of time duration/ speed in it. It starts as:

February came, and there was no reply. They wrote her a formal letter, asking her to call at the sheriff's office at her convenience. A week later the mayor wrote her himself, offering to call or to send his car for her, and received in reply a note on paper of an archaic shape, in a thin, flowing calligraphy in faded ink, to the effect that she no longer went out at all. The tax notice was also enclosed, without comment (para. 4, p. 1).

These lines are an instance of "summary", in which the events of the story are speeded up. "February came" and "a week later" show that discourse time is summarizing/ speeding up the story time. Within one line, a week passes, i.e. it takes the reader some seconds to read whereas the events in the story have actually happened in a much larger scale of time. All the events, as it was said earlier, are within the domain of the major analepsis. There is a line (italicized) in paragraph 5 which shows another analepsis which is surrounded by its previous and later lines:

They called a special meeting of the Board of Aldermen. A deputation waited upon her, knocked at the door through which no visitor had passed since she ceased giving china-painting lessons eight or ten years earlier. They were admitted by the old Negro into a dim hall from which a stairway mounted into still more shadow (para. 5, p. 1).

The next paragraph is another example of pause that describes the setting, i.e the house, the darkness and the smell in the house. Miss Emily's appearance is also described in this pause.

The $7^{\text {th }}$ paragraph is a dialogue between Miss Emily and visitors which is about taxes that she avoids paying. This dialogue can be categorized as "scene" according to Genette's model:

Her voice was dry and cold. "I have no taxes in Jefferson. Colonel Sartoris explained it to me. Perhaps one of you can gain access to the city records and satisfy yourselves."

"But we have. We are the city authorities, Miss Emily. Didn't you get a notice from the sheriff, signed by him?" 
"I received a paper, yes," Miss Emily said. "Perhaps he considers himself the sheriff ... I have no taxes in Jefferson."

"But there is nothing on the books to show that, you see. We must go by the--"

"See Colonel Sartoris. I have no taxes in Jefferson."

"But, Miss Emily-"

"See Colonel Sartoris." (Colonel Sartoris had been dead almost ten years.) "I have no taxes in Jefferson. Tobe!" The Negro appeared. "Show these gentlemen out" (para. 7, p. 2).

In this a dialogue, discourse time corresponds to story time meaning that the events in the story consumes the same time as one is reading this story.

In this dialogue and in the line before it, Miss Emily is 70 years old. After this dialogue there is a sentence that little by little leads the story to another analepsis which is thirty years earlier. This shift is created artistically immediately after the dialogue:

So she vanquished them, horse and foot, just as she had vanquished their fathers thirty years before about the smell. That was two years after her father's death and a short time after her sweetheart- the one we believed would marry her-had deserted her. After her father's death she went out very little; after her sweetheart went away, people hardly saw her at all. A few of the ladies had the temerity to call, but were not received, and the only sign of life about the place was the Negro man — a young man then — going in and out with a market basket (p. 2).

Paragraph 9, again a dialogue between the neighbors and Judge Steven, the mayor, takes place which is another instance of scene. The next paragraph in page 3 is:

"So the next night, after midnight, four men crossed Miss Emily's lawn and slunk about the house like burglars (...)"

which is again another case of summary. The phrase "next night", determines and attest to this fact.

There are some beginning lines in paragraph 15 starting with "she was sick for a long time", which is a case of summary and ellipsis. It is summary because this long time has not been felt by readers and this long time passes as soon as a single second passes. It is an ellipsis since the reader did not read anything about the difficulties and concerns that Miss Emily had. Her sickness was a part with no detail, i.e. the details are deleted.

She was sick for a long time. When we saw her again, her hair was cut short, making her look like a girl, with a vague resemblance to those angels in colored church windows - sort of tragic and serene. (para. 15, p. 3).

This very case, i.e. summary and ellipsis takes place in this passage as well:

Whenever you heard a lot of laughing anywhere about the square, Homer Barron would be in the center of the group. Presently we began to see him and Miss Emily on Sunday afternoons driving in the yellow-wheeled buggy and the matched team of bays from the livery stable (p. 4).

Nothing is said about the relationship between Homer and Ms Emily, neither in this passage, nor in any other parts of the story, as if this part is deleted.

In the above paragraph (para. 15, p. 3), there is a point about the italicized word "hair". It is repeated throughout the story for 3 or 4 times and it is a case of repetitive narration. It is believed that this case of frequency in narration happens when an event is of special importance or when it is emphasized. There are other cases where such references to "hair" and its "color" are done. They are in pages 5 and 7:

When we next saw Miss Emily, she had grown fat and her hair was turning gray. During the next few years it grew grayer and grayer until it attained an even pepper-and-salt iron-gray, when it ceased turning. Up to the day of her death at seventy-four it was still that vigorous iron-gray, like the hair of an active man (p. 5).

And in:

Then we noticed that in the second pillow was the indentation of a head. One of us lifted something from it, and leaning forward, that faint and invisible dust dry and acrid in the nostrils, we saw a long strand of iron-gray hair (p. 7).

In the last paragraph of this story (p. 7) the importance of "hair" becomes evident, in that it is repeated three times and it is a case of repetitive narration. The third point is that this paragraph is a pause since the story events are interrupted and some descriptive statements appear on the page: "making her look like a girl, with a vague resemblance to those angels in colored church windows-sort of tragic and serene" (para. 15). 
There is a part in the story where Miss Emily decides to buy poison. This event, i.e. "buying" is narrated just once in the story, thus is a singulative narration from the view point of frequency. In this part:

Like when she bought the rat poison, the arsenic. That was over a year after they had begun to say "Poor Emily," and while the two female cousins were visiting her (p.4).

'Summary' technique is manipulated since we see a year has passed in this small paragraph.

In the next paragraph of the same page, there is a mixture of "scene" and "pause". I have italicized such parts. Pause, appears between the textures of scene:

"I want some poison," she said to the druggist. She was over thirty then, still a slight woman, though thinner than usual, with cold, haughty black eyes in a face the flesh of which was strained across the temples and about the eye-sockets as you imagine a lighthouse-keeper's face ought to look. "I want some poison," she said.

"Yes, Miss Emily. What kind? For rats and such? I'd recom-"

"I want the best you have. I don't care what kind."

The druggist named several. "They'll kill anything up to an elephant. But what you want is_-"

"Arsenic," Miss Emily said. "Is that a good one?"

"Is ... arsenic? Yes, ma'am. But what you want_-"

"I want arsenic."

The druggist looked down at her. She looked back at him, erect, her face like a strained flag. "Why, of course," the druggist said. "If that's what you want. But the law requires you to tell what you are going to use it for."

Miss Emily just stared at him, her head tilted back in order to look him eye for eye, until he looked away and went and got the arsenic and wrapped it up. The Negro delivery boy brought her the package; the druggist didn't come back. When she opened the package at home there was written on the box, under the skull and bones: "For rats" (p. 4).

This dialogue can be in the category of scene because the story and discourse time are nearly the same. But there are some sentences which appear in some parts of this dialogue, like when the narrator describes her appearance and like the way Miss Emily looks at the druggist. These italicized parts are a kind of pause, as well, since the events of the story are stopped. An evident case of ellipsis can be identified in:

Then some of the ladies began to say that it was a disgrace to the town and a bad example to the young people. The men did not want to interfere, but at last the ladies forced the Baptist minister-Miss Emily's people were Episcopal - to call upon her. He would never divulge what happened during that interview, but he refused to go back again. The next Sunday they again drove about the streets, and the following day the minister's wife wrote to Miss Emily's relations in Alabama (p. 5).

In this part, the reader does not know what happened between the Baptist and Miss Emily. The reader neither knows what kind of talk was exchanged between the two. The reader is provided with no information on the content of their interview, so a case of ellipses has occurred.

In the last parts of the story, the paragraphs are more devoted to "pause" and a paragraph to "stretch". In this part:

The two female cousins came at once. They held the funeral on the second day, with the town coming to look at Miss Emily beneath a mass of bought flowers, with the crayon face of her father musing profoundly above the bier and the ladies sibilant and macabre; and the very old men - some in their brushed Confederate uniforms - on the porch and the lawn, talking of Miss Emily as if she had been a contemporary of theirs, believing that they had danced with her and courted her perhaps, confusing time with its mathematical progression, as the old do, to whom all the past is not a diminishing road but, instead, a huge meadow which no winter ever quite touches, divided from them now by the narrow bottle-neck of the most recent decade of years (p. 6).

The funeral is being described. The women, the uniforms of old men, their talk with Miss Emily, and their memories of the dances they had with her. This is actually a rich and meaning full paragraph that should be considered more in details. The concept of "time", as a general term (which may include aging, passage of time, and the inability to stop it or even fight with it), is stressed in the last lines of this paragraph by the elders who are almost the same age as Miss Emily. Their view of time is not that they are at one end and the "past" at another. But they see "past" as a huge meadow which no winter ever quite touché. They do not see past diminishing, but see it as an inseparable part of their present. I think, for these old people, time is like a circle and their past is not far from them. It is like a dot on this circle and it can be reached easily. They have not lost their past and to them, their past is as near as the present.

After this paragraph, another instance of "pause" can be seen. To this point, readers experience a sort of suspense and this suspense is intensified more and more by this "pause": 
The violence of breaking down the door seemed to fill this room with pervading dust. A thin, acrid pall as of the tomb seemed to lie everywhere upon this room decked and furnished as for a bridal: upon the valance curtains of faded rose color, upon the rose-shaded lights, upon the dressing table, upon the delicate array of crystal and the man's toilet things backed with tarnished silver, silver so tarnished that the monogram was obscured. Among them lay a collar and tie, as if they had just been removed, which, lifted, left upon the surface a pale crescent in the dust. Upon a chair hung the suit, carefully folded; beneath it the two mute shoes and the discarded socks (p. 7)

These descriptions make the reader curious about what is going on in that mysterious room. There is some evidence that suggest a catastrophe. The room furnished as for a "bridal" and then a "collar" and "tie" make the reader ready for what will occur later in the story, i.e. in the last paragraph. These descriptions can be said as a kind of implicit prolepsis since they result in a curiosity which leads to a sort of guess of what have happened. By this "pause", events are frozen and the reader is eager to know what is happening, until he reads the last paragraph of this story in which every question is answered and no enigma exist anymore:

The man himself lay in the bed. For a long while we just stood there, looking down at the profound and fleshless grin. The body had apparently once lain in the attitude of an embrace, but now the long sleep that outlasts love, that conquers even the grimace of love, had cuckolded him. What was left of him, rotted beneath what was left of the nightshirt, had become inextricable from the bed in which he lay; and upon him and upon the pillow beside him lay that even coating of the patient and biding dust. Then we noticed that in the second pillow was the indentation of a head. One of us lifted something from it, and leaning forward, that faint and invisible dust dry and acrid in the nostrils, we saw a long strand of iron-gray hair (p. 7).

In the above passage, the instance of time duration, i.e. "pause", is evident. The story events are frozen. They are interrupted to make room for more narratorial discourse. The narrator describes a static setting. This last pause is so crucial to the significance of the whole story. It is a pause without which no completion and no result would be achieved. By this pause, the reader through his/ her process of understanding the story, finds out what Miss Emily has done and what has happened to Homer, her lover. This last passage can be interpreted as "stretch" of time, as well. "Stretch", as a factor added by Prince (1982) to time category, is close to "pause". In some passages, like the above one, their borders are so close that identifying each, needs careful analysis and consideration. For example, in this part: "The man himself lay in the bed. For a long while we just stood there, looking down at the profound and fleshless grin" the description of Homer's grin can be counted as stretch because the grin that we see, takes less than a second; but what we as readers read actually takes more time. Homer's grin, if in a film, could function as a slow motion. This part continues as: "The body had apparently once lain in the attitude of an embrace, but now the long sleep that outlasts love, that conquers even the grimace of love, had cuckolded him". Here, Homer's eternal sleep is described and his sleep is slowed down to create a feeling of empathy and love and also to emphasize his death.

\section{Conclusion}

Time, with all its complexity, can be put in a framework to be studied and analyzed as what had been done in the present study. This study of "time" in Faulkner's "A Rose for Emily" has arrived a number of findings. Firstly, understanding and grasping the "time" of a story leads to a deeper and better understanding of the content (events and plot) of that story. Knowing the principles of time, preferably in a framework (like Genettes model that was just presented in this study), will let readers access the deep structure of the story and also to be able to come to a wider and multiple interpretations of stories. Secondly, analepsis and prolepsis, as two main narrative techniques in the category of "time" and specifically the sub-categories of "order", can be perplexing enough to make readers exhausted of reading a story. So the ability that an individual achieves in identifying analepsis and prolepsis, will give him/her a better and a more clear understanding of a story. Furthermore, these two techniques can make clear the borders of the past, present, and future in a story. Therefore, readers will not be lost in 'time' when they are reading a story. Because being lost in time means the inability of coming to a cohesive understanding of what is going on in the story.

\section{References}

Augustine (1992). Confessions. 3 Vol., Vol. 1: Introduction and Text. Oxford: Clarendon P.

Abbott, H. P. (2002). The Cambridge Introduction to Narrative. Cambridge, UK: Cambridge University Press.

Bal, M. (1991). Narration and Focolization. In Bal, M. (Ed.). (2004). Narrative theory, Vol. 1. (pp. 263-296). London: Routledge.

Barthes, R. (1977) Introduction to the Structural Analysis of Narratives. In Mcquillan, M. (Ed.). (2000). (pp. 109-114). The Narrative Reader. London: Routledge.

Bruner, J. (1991) 'The Narrative Construction of Reality', in Critical Inquiry, 18(1), p.6.

Chatman, S. (1978). Story and Discourse. Narrative Structure in Fiction and Film. Ithaca: Cornell UP.

Fludernik, M. \& Margolin, U. (2004). "Introduction.” Special Issue German Narratology I of Style, 38, 148-87. 
Fludernik, M. (2006). An Introduction to Narratology. New York: Routledge.

Genette, G. (1980). Narrative Discourse: An Essay in Method. Trans. Jane Lewin. Ithaca: Cornell University Press.

Heidegger, M. (1971) Poetry, Language, Thought. New York: Harper \& Row.

Herman, D. (2009). Basic Elements of Narrative. Malden, MA: Wiley-Blackwell.

Jahn, M. (2005). Narratology: A guide to the theory of narrative. English department: University of Cologne. Retrieved November 10, 2006, from: www.uni-koeln.de/ame02.pppn.htm.

Lessing, G. E. (1962). Laocoön. An Essay on the Limits of Painting and Poetry. Indianapolis: Bobbs-Merrill.

Meister, J. Ch. (n. d.). Narratology. In Hühn, P., Pier, J., Schmid, W., \& Schonert, J. (Eds.). (2009). Handbook of Narratology. Walter de Gruyter: Berlin.

Nash, C. (1994). Narrative in culture. London: Routledge.

Kindt, T \& Müller, H. H. (2003). “Narrative Theory and/or/as Theory of Interpretation.” T. K. \& H.-H. M. (Eds.). What Is Narratology? Questions and Answers Regarding the Status of a Theory. Berlin: de Gruyter, 205-19.

Phelan, J. \& Robinowitz, P. J. (Eds.). (2006). A Companion to Narrative Theory. Oxford: Blackwell.

Prince, G. (1982). Narratology: The Form and Functioning of Narrative. Walter de Gruytcr \& Co.: Berlin.

Prince, G. (1990). On Narratology (past, present, future). French literature series (Columbia), 17 (1). In Macquillqn, M. (Ed.). (2000). The Narrative Reader. (p. 129). London: Routledge.

Prince, G. (2003). A Dictionary of Narratology. Lincoln: U of Nebraska P.

Scheffel, M., Weixler, A.,Werner, L. (2013). "Time”. In Hühn et al. (Eds.): The Living Handbook of Narratology. Hamburg: Hamburg University. URL = http://www.lhn.uni-hamburg.de/article/time.

Ricour, P. (1980)."Narrative Time". Critical Inquiry. 7. pp.169-176.

Ricoeur, P. (1984-1989). Time and Narrative, Vols 1-4. Chicago, IL: University of Chicago Press.

Rimmon-Kenan, Sh. (1983). Narrative fiction: Contemporary poetics. London: Methuen.

Rimmon-Kenan, Sh. (2004). Towards...afterwards, almost twenty years later. In Bal, M. (Ed.). (2004). Narrative theory, Vol 1. (pp. 42-55). London: Routledge.

Ryan \& Alphen, E. V. (1993). “Narratology.” I. R. Makaryk (ed). Encyclopedia of Contemporary Literary Theory. Approaches, Scholars, Terms. Toronto: U of Toronto P, 110-16.

Todorov, T. (1969). “The Two Principles of Narrative.” Diacritics 1, 37-44.

Todorov, T. (1971). “The Two Principles of Narrative.” Diacritics 1, 37-44.

Tomaševskij, B. (Tomashevsky) (1925/ 1965). “Thematics.” P. A. Olson (Ed.). Russian Formalist Criticism. Four Essays. Lincoln: U of Nebraska P, 59-95.

Toolan, M. (2001). Narrative: A Critical Linguistic Introduction. London: Routledge.

Whatling, S. (2010). Narrative art in northern Europe, c.1140-1300: A narratological re-appraisal. (Doctoral dissertation, The Courtauld Institute of Art, University of London) Retrieved December 8, 2014, from: http://www.medievalart.org.uk/PhD/Contents.html. 